\title{
КУЛЬТУРНО-ИСТОРИЧЕСКОЕ НАСЛЕДИЕ СТРАНЫ КАК ОСНОВА ВОСПИТАНИЯ ПАТРИОТИЧЕСКИХ ЧУВСТВ У ДЕТЕЙ СТАРШЕГО ДОШКОЛЬНОГО ВОЗРАСТА
}

\author{
Е. В. Елисеева \\ Московский гуманитарный университет
}

\begin{abstract}
Аннотация: В статье рассматривается вопрос патриотического воспитания детей старшего дошкольного возраста. Автор делится опытом своей работы и утверждает о целесообразности использования культурно-исторического наследия Родины в процессе воспитания.

Ключевые слова: патриотическое воспитание; старший дошкольный возраст; культурное наследие; историческое наследие; Родина; дошкольное образование

\section{CULTURAL AND HISTORICAL HERITAGE OF THE COUNTRY AS THE BASIS FOR THE INSTILLING OF PATRIOTIC FEELINGS IN PRESCHOOL AGE CHILDREN}

\author{
E. V. Yeliseyeva \\ Moscow University for the Humanities
}

Abstract: The article considers the issue of patriotic education of preschool age children. The author shares her work experience and argues the expedience of the use of cultural and historical heritage of our Motherland in the process of education.

Keywords: patriotic education; preschool age; cultural heritage; historical heritage; Motherland; preschool education

Во всём мире, в каждой стране есть святые места. В нашем государстве подобных мест немало. Воспитание подрастающего поколения в России всегда сопровождалось с воспитанием чувства гордости за свою Родину, чувством патриотизма и любви к своему великому, могучему народу.

Современный этап развития дошкольного образования характеризуется быстрым темпом внедрения инновационных технологий в практику работы детских садов. Ни для кого не секрет, что научно-технический прогресс, четвёртая промышленная революция, технологические новации заставляют работников образования находиться в постоянном «тонусе», чтобы вдруг не оказаться неинтересными своим воспитанникам. Воспитатель дошкольного образования должен владеть новейшими технологиями в об- 
Научные труды Московского гуманитарного университета 2018 № 4

ласти обучения и воспитания детей, а также обладать широкой эрудицией, педагогической интуицией, высокоразвитым интеллектом с высоким уровнем нравственной культуры.

Появилось новое понятие «профессиональная компетентность», что означает способность эффективно осуществлять педагогическую деятельность, определённую конкретными должностными обязанностями. Профессиональная компетентность предполагает, что воспитатель дошкольного образования в совершенстве владеет необходимой базой профессионально значимых установок, теоретических знаний, умений и навыков, которые он будет совершенствовать в процессе самообразования.

Мы - воспитатели - изучаем новые стандарты, новейшие технологии, к нам предъявляют соответствующие требования. Мы должны научить детей делать правильный нравственный выбор, высказывать своё мнение, и умение отстаивать его. Однако, есть и всегда будут две главные задачи, которые мы должны решать. Первая - сохранить здоровье ребёнка, научить его самостоятельно оберегать своё здоровье, приумножая его. Вторая привить и развить у воспитанников чувство патриотизма, любви к своей семье, своему дому, окружающему миру, и любви к своему Отечеству.

Цель данной статьи - показать, насколько важно, необходимо и, в то же время, не сложно воплощать на практике замыслы патриотического воспитания уже в дошкольном детстве.

Для этого мы на примерах из личного опыта работы продемонстрировать доступность восприятия и желание детей участвовать в различного рода мероприятиях, посвящённых знакомству с историей своей Родины, героическими подвигами соотечественников; расскажем об эффективности подобных мероприятий и сформулируем некоторые методические рекомендации коллегам.

О любви к Родине, как известно, мы говорим детям уже с начала учебного года, объясняя им, что любовь к семье, друзьям, детскому саду, к окружающему миру - это и есть любовь к своей стране.

Детям обязательно задаётся вопрос: «Почему мы любим Родину?» Из своего опыта могу сказать, что в старшем дошкольном возрасте ребята с удовольствием отвечают на этот вопрос без помощи воспитателя.

На занятиях дети знакомятся с культурой и историей российского государства, с известными личностями в соответствие с проектом воспитателя по данной теме. И, необходимо заметить, что работа над проектом не только с удовольствием воспринималась детьми, но и помогала педагогу решить одновременно целый комплекс образовательных, воспитательных и развивающих задач. Подобные мероприятия направлены на приобщение дошкольников к культурно-историческому наследию своей страны и 
воспитание у них патриотических чувств, и реализовывались в самой различной форме: беседы, рассказы, инсценировки, презентации, игры-путешествия, просмотр мультфильмов с обязательными комментариями и беседами об увиденном, походы в музеи и другое. Немаловажно, детьми были подготовлены доклады при помощи родителей и воспитателя на темы: «Мое Отечество, как все зарождалось». К выступлению детей были добавлены мультфильмы «Богатыри земли руссокй», «Илья Муромец». Использовались репродукции картин В. В. Васнецова «Богатыри» и другие картины батального жанра.

Далее дети самостоятельно выбирали тему своего проекта, об известных личностях, которыми гордится наше Отечество. В течение года дети презентовали свои проекты сверстникам, так же и детям из других групп. Всем ребятам очень было интересно познакомиться с общепризнанными личностями Российского государства: Сергием Радонежским, Д. И. Донским, Александром Невским, императрицей Екатериной Великой, со знаменитыми полководцами А. В. Суворовым, М. И. Кутузовым. Очень интересно были подготовлены доклады об А. С. Пушкине, П. М. Третьякове, В. В. Васнецове, Юрии Гагарине и многих других.

Интересно то, что дети привносят что-то свое к легендарной личности, о которой они делают доклад. К примеру, выступающий ребенок, рассказывающий о Дмитрии Донском, для большего интереса ребят оделся в костюм - доспехи и принес копию старинного меча. На доклад о М. И. Кутузове ребенок принес настоящие пистоли того времени, чем еще больше заинтересовал своим рассказом сверстников. Презентацию-мультфильм о Сергии Радонежском родители вместе с ребенком делали самостоятельно, рисуя и «оживляя» каждый кадр с проникновенным рассказом о его служении Отчизне. В рассказе о А. С. Пушкине дети увидели прекрасную красочную презентацию и услышали от ребенка-докладчика наизусть выученное вступление к поэме «Руслан и Людмила» «У Лукоморья дуб зеленый». Рассказ о П. М. Третьякове и В. В. Васнецове сопровождался известными репродукциями, некоторые дети картинки принесли на доклад. Каждый доклад был очень красочный, познавательный и интересный. Уже к середине учебного года почти все дети с удовольствием выступили и с большим желанием готовили следующие доклады.

Необыкновенно познавательным и захватывающим оказался видеопроекты «Природные чудеса России». Дети подобрали вместе с родителями очень интересный материал, рассказав не только об обширной территории нашей страны и ее богатствах, но и о природных чудесах: вулкане Эльбрусе, озере Байкал, Долине гейзеров, каменных грибах на Алтае, подводной пещере Орде, северном сиянии в Заполярье, Кунгурской ледяной пещере, 
Научные труды Московского гуманитарного университета 2018 № 4

«полюсе холода» и многом другом.

Получилось, что это позволило детям и получить новые знания о богатствах и чудесах нашей Родины, и поговорить о защите природы.

В начале всех докладов по сложившейся традиции дети предлагали слушателям отгадать загадки. Также подготавливали тематические пословицы, поговорки и скороговорки, и после своей презентации раздавали, приготовленные заранее раскраски по теме. Вместе с родителями и воспитателем придумывали к своему докладу: подвижные игры, игры-забавы, увлекательные задания с преодолением препятствий, различную продуктивную деятельность, задания на смекалку, выносливость, внимание, на проявление нравственных качеств.

В группе были осуществлены и коллективные проекты: «Герои моей семьи», «Открытка ветерану - благодарность потомков». Проект «Картотека пословиц, поговорок о Русской Земле» сопровождался большим комплексом мероприятий. Прежде всего детям было дано задание узнать дома у родителей, бабушек, дедушек пословицы и поговорки о русской земле. Все пословицы мы с детьми обсуждали, определяли, что можно нарисовать, иллюстрируя текст, так что дети были подготовлены. Таким образом, в нашей группе появился большой альбом «Картотека пословиц, поговорок о Русской Земле» с рисунками к каждой из них, который постоянно и с удовольствием пополняется.

Следующим мероприятием этого проекта был конкурс «Отгадай или покажи пословицу». Были подобраны те тексты, которые можно показать в действии, но без слов. С большим восторгом дети выполняли условия этой игры.

Ко Дню Победы был подготовлен концерт для ветеранов: «Спасибо прадеду за победу», где все воспитанники группы пели патриотические песни о подвигах нашего народа и о любви к своему Отечеству, рассказывали специально написанные для проекта патриотические стихи, танцевали. Мальчики были одеты в военные гимнастёрки и матросские тельняшки, а девочки в форму санитарок и радисток. Все прошло очень достойно и очень трогательно.

К этому же Великому празднику Победы в помещении группы был сделан руками родителей и детей стенд «Бессмертный полк», на который воспитанники прикрепляли фотографии героев своей семьи. При этом, ребёнок, помещавший на стенд фотографию, с гордостью рассказывал о подвиге героя, в презентации показывая его военные фотографии.

В День Победы все дети поздравляли не только родственников, но и соседей-ветеранов, причастных к этому празднику, открытками, выполненными своими руками. Прикрепили на уличный стенд большой плакат, сде- 
ланный руками детей, посвященный Великой Победе.

«Спешите делать добрые дела!» - наш постоянный проект, приуроченный к году волонтера. Деятельность детей в его реализации направлена на то, чтобы научиться делать как можно больше добрых дел. Дети смогли проявить самые лучшие свои нравственные качества и с удовольствием рассказывали о том кому они смогли помочь или кого спасти.

В современном обществе воспитатель - одна из самых важных и востребованных профессий. Образовывая, он помогает детям в становлении их субъективности, социализации, закладывает основу высоконравственной личности.

Воспитатель дошкольного образования - это не просто профессия, а призвание и каждодневный колоссальный труд. Научить детей не только гордиться своей Родиной, но деятельностно полюбить ее - ответственная, интересная и главное необходимая, живая форма работы. Научить быть патриотам только по книжкам невозможно. Поэтому нам в этом деле помогают фильмы, мультфильмы, презентации, рассказы. Дети берут пример, «примеряют» на себе высшие нравственные качества, которые потом проявляют уже в повседневной жизни.

От того как мы воспитаем подрастающее поколение зависит суверенитет и самобытность нашего Отечества, сможет ли Россия развиваться, стать современной, перспективной и главное мощной державой зависит от каждого из нас лично.

Дата поступления: 15.08.2018 2.

Елисеева Елена Владимировна - магистрант кафедры педагогики и психологии высшей школы Московского гуманитарного университета. Адрес: 111395, Россия, г. Москва, ул. Юности, д. 5. Тел.: +7 (499) 374-74-59. Эл. адрес: elena.0470@mail.ru Научный руководитель - д-р пед. н., проф. Л. В. Романюк.

Yeliseyeva Elena Vladimirovna, Graduate Student, Department of Pedagogy and Psychology of Higher School, Moscow University for the Humanities. Postal address: 5, Yunosti St., Moscow, Russian Federation, 111395. Tel.: +7 (499) 37474-59. E-mail: elena.0470@mail.ru. Scientific Advisor - L. V. Romanyuk, Doctor of Pedagogy, Professor 


\section{Для цитирования:}

Елисеева Е. В. Культурно-историческое наследие страны как основа воспитания патриотических чувств у детей старшего дошкольного возраста [Электронный ресурс] // Научные труды Московского гуманитарного университета. 2018. № 4. URL: http://journals.mosgu.ru/trudy/article/view/817 (дата обращения: дд.мм.гг.). DOI: 10.17805/trudy.2018.4.13 